\title{
High Pressure Growth Approach for the Preparation of Reduced Graphene Oxide and its Investigation Using Raman Spectroscopy
}

\author{
Mamta Thakran ${ }^{1}$, Sumeet Kumar ${ }^{1}$, Rohit Phogat ${ }^{1}$, S.K. Ray ${ }^{2}$, R. Brajpuriya ${ }^{3}$, Abhimanyu Singh Rana ${ }^{4}$ \\ Brijesh Kumar $1,5,6, *$ \\ ${ }^{1}$ Centre for Nano Science \& Technology, Amity Institute of Nanotechnology, Amity University, Haryana, India \\ 2 Centre for Stem Cell, Amity Institute of Biotechnology, Amity University, Haryana, India \\ 3 University of Petroleum and Energy Studies, Department of Physics, School of Engineering, Dehradun, India \\ ${ }^{4}$ BML Munjal University, Gurugram, Haryana, India \\ 5 Amity School of Engineering \& Technology, Amity University, Haryana, India \\ ${ }^{6}$ Amity Institute of Laser Technology \& Optoelectronics, Amity University, Haryana, India
}

(Received 21 March 2021; revised manuscript received 06 August 2021; published online 20 August 2021)

\begin{abstract}
Graphene derivatives show extraordinary mechanical, optical, and electronic properties, which gave rise to high scientific interest and huge potential for a variety of applications. Raman spectroscopy is a versatile tool to characterize and identify the chemical and physical properties of graphene derivatives. We describe essential Raman scattering processes of the first- $(G)$ and second-order (D, G*, 2D, G + D, 2G) modes in GO and r-GO prepared by a high-pressure growth approach. In r-GO, the linewidth is broadened and slightly red-shifted in all the bands, in comparison with GO because of strain development during the high-pressure growth approach (hydrothermal process) as a result of removal of oxygen functionalities. A normalized intensity ratio $\left(I_{\mathrm{D}} / I_{\mathrm{G}}\right)$ for GO and r-GO is discussed. In both the samples, $I_{\mathrm{D}} / I_{\mathrm{G}}$ is high which indicates the small size of GO and r-GO and the presence of turbostratic carbon and disordered structures. The peak fitting of the $2 \mathrm{D}$ band exhibits four Lorentzian peaks, and the intensity of the $2 \mathrm{D}$ band with respect to the G band is strongly reduced, which confirms that we have successfully synthesized bilayer/ trilayer GO and r-GO. For GO and r-GO, the crystallite size $\left(L_{a}\right)$ is calculated. The existence of the $2 \mathrm{D}$ band confirms that we have successfully synthesized high-quality GO and r-GO.
\end{abstract}

Keywords: High pressure growth, Modified Hummers method, Raman spectroscopy, Graphene oxide, Reduced graphene oxide.

DOI: 10.21272/jnep.13(4).04015

PACS numbers: 81.05.ue, 81.07. - b, 61.46.Df, 78.30. $-\mathrm{j}, 81.90 .+\mathrm{c}$

\section{INTRODUCTION}

Raman spectroscopy is a very powerful tool for characterizing different types of carbon compounds. Raman scattering is an inelastic scattering of light by matter [1]. The effect is highly sensitive to chemical and physical properties of the scattering material and any environmental effect as well that can change these properties. Due to this reason, most research papers which concern carbon materials must contain at least one Raman spectrum. Raman spectrometers are broadly available. A technique, which is relatively simple, allows to perform experiments even at room temperature and under ambient pressure and does not require any sample preparation as well. Optical techniques, which do not use high-energy photons, are non-invasive as well as non-destructive, because they use a chargeless and massless particle, a photon, as a probe, that is important for nanotechnology or nanoscience. Raman spectra are extremely useful for advancing our knowledge about nanostructures.

Carbon is a neighbor of silicon in the periodic table, has unique chemical, physical and biological properties with more flexible bonding and hence holds promise for a revolution in various fields like electronics, optics and mechanics for future technologies. The following three important features make $s p^{2}$ nanocarbons (graphene/ 2D materials) special.
Mechanical strength is due to unusually strong covalent $\sigma$ (sigma) bond between neighboring carbon atoms. This is advantageous for nanomaterials, since various nanostructures (tubes, sheets, cages, ribbons, dots, etc.) are strong and stable enough for exposure to different types of processing steps and characterization techniques.

Graphene ( $s p^{2}$ nanocarbon) and its derivatives (graphene oxide, reduced graphene oxide) are also called $\pi$ (pi) electron materials, since they have extended $\pi$ electron clouds. Hence, this results in unusual delocalized electronic states in graphene-based materials, because they ( $\pi$ electrons) behave like relativistic Dirac fermions. That is why these states show a massless linear energy-momentum relationship that is responsible for unique transport (both electronic and thermal) properties at sufficiently small momentum and energy values. This kind of unusual electronic structure is also responsible for having unique optical phenomena.

The simplicity of graphene-based systems is that they are systems formed by only one type (carbon) of atoms in a periodic hexagonal structure. Therefore, unlike other materials, $s p^{2}$ based graphene systems allow us to easily access their unique properties by using both theoretically and experimentally and help us model the structure for the development of our knowledge and methodologies.

\footnotetext{
*bkumar2@ggn.amity.edu
} 
The most fundamental crystal that constitutes the basis of $s p^{2}$ nanocarbons is graphene. Graphene is a two-dimensional (2D) system, which consists of $s p^{2}$ carbon hexagonal network with very strong covalent bonds between $\mathrm{C}-\mathrm{C}$ atoms.

Carbon atoms are present at the vertices of hexagons (Fig. 1a), and two carbon atoms per unit cell can be used to reproduce the entire structure of graphene by applying appropriate translational symmetries/ operations. When many graphene layers are placed on top of each other, the resulting three-dimensional (3D) structure will be of graphite. Multilayer graphene can be stacked layer-by-layer in Bernal (AB) or rhombohedral (ABC) way (Fig. 1b, c), having van der Waals coupling in the layers [2].
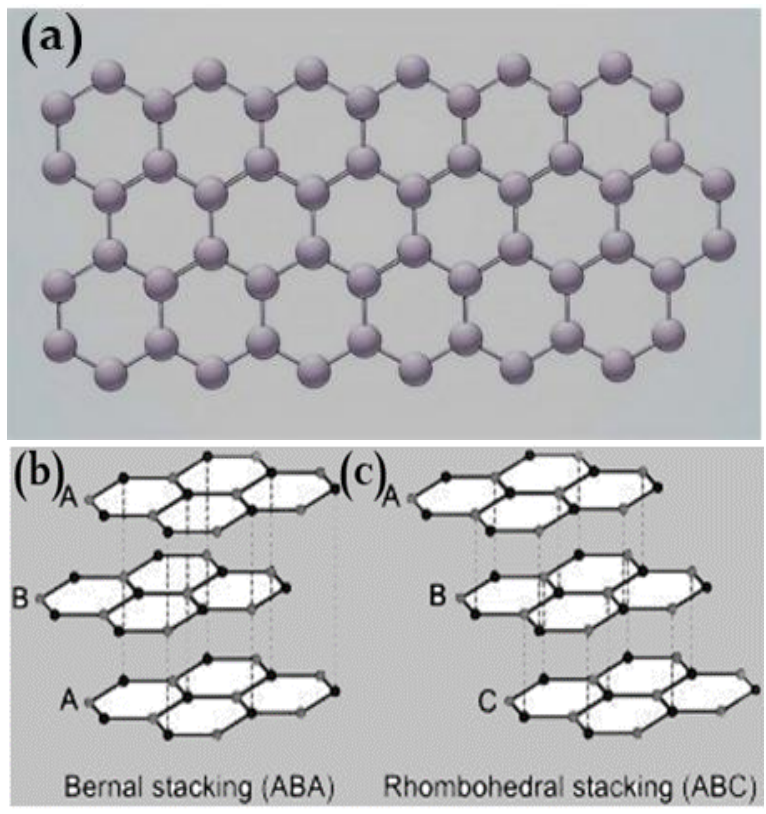

Fig. 1 - (a) Simple chain of carbon atoms that are hexagonally packed, (b) trilayer of graphene showing Bernal stacking (AB/ABA), and (c) trilayer of graphene showing rhombohedral stacking $(\mathrm{ABC})$

Graphene oxide (GO) is a compound containing carbon, oxygen and hydrogen in different ratios, obtained by treating graphite (precursor) with very strong oxidizers and then exfoliating in water. GO has a very broad range of properties, depending on the oxidation degree and synthesis process, and is known as a promising precursor for mass production of graphene derivatives (reduced graphene oxide) and devices [3], since there are many oxygen-containing functional groups (epoxy, carboxy, hydroxy and carbonyl) in GO, which make GO insulating and hence restrict its applications in electronics [4]. Reduction of GO to produce reduced graphene oxide (r-GO) has been used in mass production of graphene. Till date, significant research efforts have been made to reduce GO, as evidenced by a huge number of related publications [4-6]. Initially, methods for reducing GO could be simply divided into two types, the first is chemical reduction and the other is thermal treatment [7]. Afterwards, electrochemical reduction and annealing came into light to produce r-GO [8]. The reduction of GO to $\mathrm{r}-\mathrm{GO}$ is an important process since it has a significant impact on the quality of the produced
$\mathrm{r}-\mathrm{GO}$, and hence it is important to determine how similar r-GO will be to pristine graphene, in terms of structure. Raman spectroscopy proves its ability to characterize GO and r-GO [9, 10].

In this research paper, the general pattern of the Raman spectra of GO and r-GO is first established. For this purpose, GO is synthesized by modified Hummers method, while r-GO is synthesized from the above prepared GO by high-pressure growth approach using an autoclave, and their Raman spectra are very well analyzed in detail. Subsequently, the appearance of the $G$ band, multiple defects activated bands like $\mathrm{D}$ band and $2 \mathrm{D}\left(\mathrm{G}^{\prime}\right)$ band, linewidth broadness, dispersion of positions and intensities of the bands, etc. have been illustrated in this high-pressure grown material system for the first time, to the best of our knowledge.

\section{EXPERIMENTAL DETAILS}

\subsection{Material Synthesis}

GO was prepared by modified Hummers method from high-purity microcrystalline graphite (size, $99.9 \%$, Alfa Aesar), sulfuric acid (98\%), nitric acid (68\%), potassium permanganate $(99 \%)$, hydrogen peroxide (30\%), hydrochloric acid (37\%), and deionized water was used for washing.

Synthesis of GO

Briefly, graphite (5 g), $\mathrm{NaNO}_{3}(2.5 \mathrm{~g})$ were mixed in cooled concentrated sulfuric acid $(108 \mathrm{ml})$ and orthophosphoric acid $(12 \mathrm{ml})$ under stirring in an ice bath for 10 min. $\mathrm{KMnO}_{4}$ (15 g) was gradually added to the above placed mixture with stirring and cooling so that the temperature of the mixture was maintained below $5{ }^{\circ} \mathrm{C}$. The reaction mixture was then stirred continuously at $40{ }^{\circ} \mathrm{C}$ for $30 \mathrm{~min}$ to form a thick paste. Subsequently, $160 \mathrm{ml}$ of deionized water was added to the formed paste, followed by continuous stirring for another $90 \mathrm{~min}$ at $90^{\circ} \mathrm{C}$. Later, additional $200 \mathrm{ml}$ of water was added to stop the oxidation reaction. Sequentially, $15 \mathrm{ml}$ of $30 \% \mathrm{H}_{2} \mathrm{O}_{2}$ was added in the above mixture to remove the excess of $\mathrm{KMnO}_{4}$. The complete removal of $\mathrm{KMnO}_{4}$ was indicated by a change of color into yellow. After that, the sample was washed with $\mathrm{HCl}$ (2-3 times) and deionized (distilled) water for several times till $\mathrm{pH}$ became neutral. Finally, the collected sample was dried in a vacuum oven at $65^{\circ} \mathrm{C}$ overnight.

\section{Synthesis of r-GO}

First, $100 \mathrm{mg}$ of as-synthesized GO was suspended in $50 \mathrm{ml}$ of ethylene glycol which gave a brown colloidal solution after $30 \mathrm{~min}$ of sonication. Then, the solution was transferred and sealed in a $100 \mathrm{ml}$ Teflon-lined autoclave and maintained at $160{ }^{\circ} \mathrm{C}$ in a vacuum oven for $16 \mathrm{~h}$. After that, solids were filtered and washed with acetone and deionized (distilled) water for several times till $\mathrm{pH}$ became neutral. Finally, the collected sample was dried in a vacuum oven at $65^{\circ} \mathrm{C}$ overnight.

\subsection{Characterization}

Raman spectroscopy was conducted on a Raman microscope with a CCD detector in backscattering geometry. A DPSS laser having $532 \mathrm{~nm}(2.33 \mathrm{eV})$ wavelength, $50 \mathrm{~mW}$ power with a $100 \times$ magnification objective was used for Raman measurements. The apparatus was 
calibrated with silicon reference that gave a peak position at $520 \mathrm{~cm}^{-1}$ and a resolution of less than $1 \mathrm{~cm}^{-1}$.

\section{RESULTS AND DISCUSSION}

Although the Raman spectra of GO and r-GO have a large number of peaks, most of them are comparatively weak. The most intense and widest peaks that are used to study and characterize GO and r-GO are the G and D bands. The $\mathrm{G}$ band corresponds to the first-order $E_{2 g}$ Raman allowed phonon at the Brillouin zone center. The D band corresponds to the breathing modes of sixatom rings and always requires a defect for activation. The $2 \mathrm{D}\left(\mathrm{G}^{\prime}\right)$ band related to the second order $\mathrm{D}$ peak is also very strong and important for GO and r-GO.

In various research papers, it has been mentioned that with respect to pristine graphene and graphite, additional Raman modes can be clearly observed in disordered graphene and graphite, e.g., the so-called defect/disordered $\left(\mathrm{G}^{*}, \mathrm{G}+\mathrm{D}\right.$ and $\left.2 \mathrm{G}\right)$ modes. These defect modes cannot be ascribed to vibration modes from defects themselves but resemble phonons having momentum $q \neq 0$ because of the presence of various defects in the sample. This process of induced defects is not allowed in a purely crystalline sample without any defects because of momentum conservation. The peak position, linewidth and intensity of the Raman modes change significantly with increasing number of defects in derivatives of graphene. The characteristics of these most intense features of the Raman spectra are shown in Fig. 2a and Fig. 2b for GO and r-GO, respectively.

The most significant bands in graphene derivatives are described in detail as follows.

$\mathbf{G}$ band. The $\mathrm{G}$ band is related to the $\mathrm{C}-\mathrm{C}$ bond stretching and is the most important Raman signature for all graphene derivatives. It is usually observed as a peak at around $1585 \mathrm{~cm}^{-1}$ in literatures, in our data it also comes out at 1585.04 and $1582.59 \mathrm{~cm}^{-1}$ for GO and r-GO, respectively. Generally, the $\mathrm{G}$ band of $\mathrm{r}-\mathrm{GO}$ occurs at $1582.59 \mathrm{~cm}^{-1}$ and corresponds to the recovery of hexagonal network of carbon atoms from defects, which are caused during the oxidation of graphite to form GO. The red shift in the G, D and $2 \mathrm{D}$ bands can be due to hydrostatic pressure that usually results in a decrease in the frequency of vibrational modes (phonon softening) [11]. Doping of graphene derivatives leads to a blue shift of $\omega \mathrm{G}$ for weak doping (Fermi level changes near the $\mathrm{K}$ point). A higher doping level causes a red (blue) shift for $n(p)$ doping. An increase in temperature generally leads to red shifts of $\omega \mathrm{G}$. The linewidth for the $\mathrm{G}$ peak comes out to be $51.06^{1}$ and $122.46 \mathrm{~cm}^{-1}$ for GO and $\mathrm{r}$-GO, respectively, whereas for pristine graphene, it comes out to be $10-15 \mathrm{~cm}^{-1}$. In both samples, the linewidth broadened because of strain. A large amount of strain was induced specifically in $\mathrm{r}-\mathrm{GO}$, which agrees with a slight red shift $\left(3 \mathrm{~cm}^{-1}\right)$ of the $\mathrm{G}$ band in $\mathrm{r}-\mathrm{GO}$ because of high-pressure growth approach and an increase in the temperature of the sample by placing it in an autoclave in a vacuum oven at $160^{\circ} \mathrm{C}$.

2D (G') band. The 2D band is the second-order Raman signature for all graphene derivatives. The $2 \mathrm{D}$ or G' band comes out to be in a range of $2500-2800 \mathrm{~cm}^{-1}$ for both samples (Fig. 2a, b) that agrees with the literature. The $2 \mathrm{D}$ band frequency $\omega_{2 \mathrm{D}}$ appears at 2718.67 and $2685.80 \mathrm{~cm}^{-1}$ for GO and r-GO, respectively, for $E_{\text {laser }}=2.33 \mathrm{eV}$. The sensitivity of $\omega_{2 \mathrm{D}}$ makes this band a very powerful tool for quantifying the number of graphene derivative layers. The $2 \mathrm{D}$ band has various peak profile rather than a single Lorentzian as found in single/monolayer graphene derivatives or in graphene. The splitting of the $2 \mathrm{D}$ band is due to the splitting of $\pi$ electron dispersion energies caused by the interaction between neighboring graphitic planes [12]. Additionally, the $2 \mathrm{D}$ band position is supposed to be dispersive in nature because of its double resonant origin. As the number of layers increases, the intensity of the $G$ band increases significantly, whereas intensity of the 2D band decreases as in our case of r-GO (Fig. 3) [13]

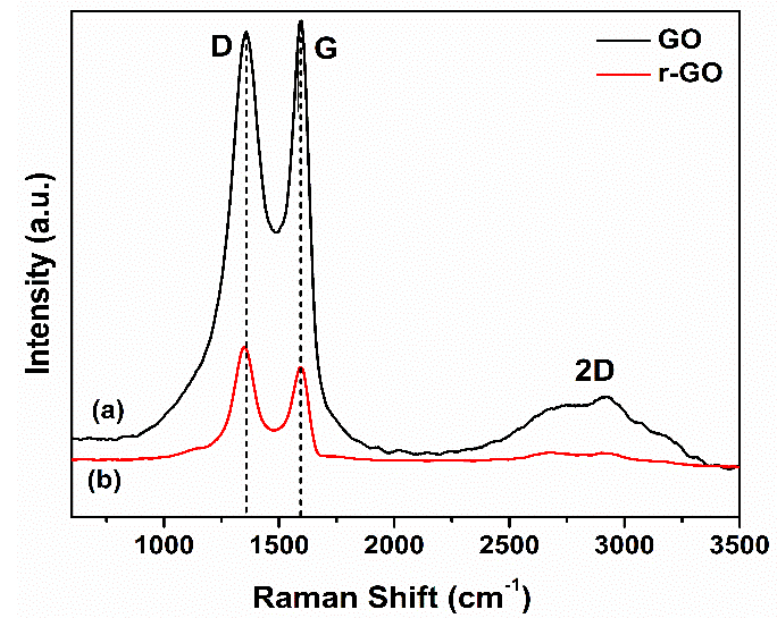

Fig. 2 - Raman spectra of crystalline (a) graphene oxide (GO) and (b) reduced graphene oxide (r-GO) at incident laser energy of $2.33 \mathrm{eV}(532 \mathrm{~nm})$

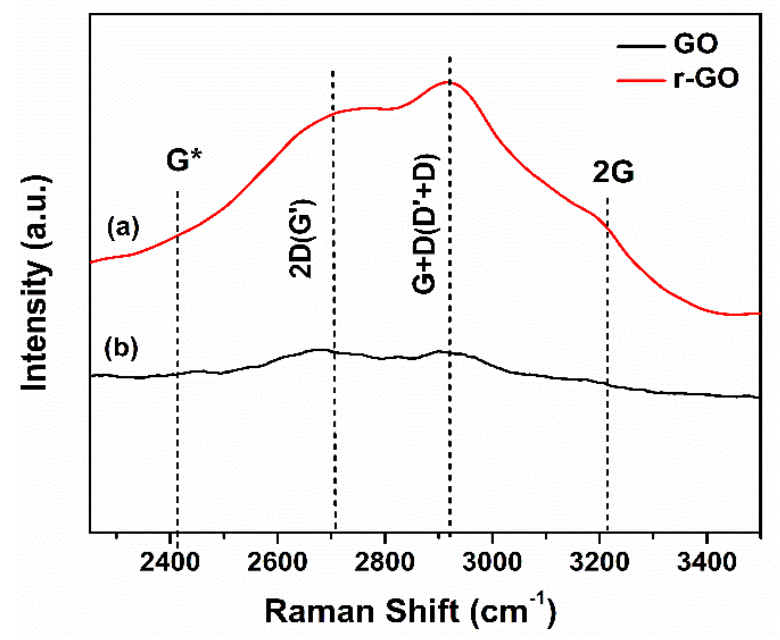

Fig. 3 - Multiple peaks for 2D region of (a) graphene oxide (GO) and (b) reduced graphene oxide (r-GO)

Generally, the 2D band depends on the number of layers; one-layer (1L) GO and r-GO exhibit a single Lorentzian peak in the $2 \mathrm{D}$ band, and the intensity of the $2 \mathrm{D}$ band is larger (about 24 times) than that of the $\mathrm{G}$ band in 1LGO and r-GO. In contrast, 2LGO and $r$-GO exhibit four Lorentzian peaks (Fig. 3a, b) in the $2 \mathrm{D}$ band, and the intensity of the $2 \mathrm{D}$ band with respect to the $\mathrm{G}$ band is strongly reduced (as in our case for both samples). For $3 \mathrm{LGO}$ and r-GO, 15 scattering pro- 
cesses can happen for the $2 \mathrm{D}$ band, but all 15 peaks occur very close in frequency, hence, cannot be distinguished from each other. The ratio between the intensities of the $2 \mathrm{D}$ and $\mathrm{G}$ bands $\left(I_{2 \mathrm{D}} / I_{\mathrm{G}}\right)$ is used as a revealer of the number of GO and r-GO layers present, a value around 2.0 is associated with a monolayer, whereas lower values indicate few layers of GO and r-GO. The spectra in Fig. $2 \mathrm{a}, \mathrm{b}$ are analyzed and the $I_{2 \mathrm{D}} / I_{\mathrm{G}}(0.06$ for GO and 0.13 for $\mathrm{r}-\mathrm{GO}$ ) ratio is determined using the areas under the peaks.

The $2 \mathrm{D}$ band is slightly red shifted $\left(33 \mathrm{~cm}^{-1}\right)$ for r-GO compared to GO, which is due to the development of local strain [14] during high-pressure growth method that leads to the removal of oxygen-containing functional groups.

The $2 \mathrm{D}$ band can be easily observed only when the crystallinity of GO and r-GO is very high (pristine or few defects), it can be considered as an indicator of relatively high quality of GO and $\mathrm{r}-\mathrm{GO}$, hence this proves that GO and r-GO synthesized above are of high quality.

Table 1 - Frequency behavior of Raman modes of materials based on graphene derivatives (GO and r-GO)

\begin{tabular}{|c|c|c|c|}
\hline $\begin{array}{c}\text { Raman } \\
\text { bands/peaks }\end{array}$ & $\begin{array}{c}\omega\left(\mathrm{cm}^{-1}\right) \\
\mathrm{GO}\end{array}$ & $\begin{array}{c}\omega\left(\mathrm{cm}^{-1}\right) \\
\mathrm{r}-\mathrm{GO}\end{array}$ & Res $^{(1)}$ \\
\hline $\mathrm{D}$ band & 1357.01 & 1349.94 & DRd1 \\
\hline $\mathrm{G}$ band & 1585.04 & 1582.59 & SR \\
\hline $\mathrm{G}^{*}$ band & 2390.54 & 2410.06 & DR2 \\
\hline $2 \mathrm{D}\left(\mathrm{G}^{\prime}\right)$ band & 2718.67 & 2685.80 & DR2 \\
\hline $\mathrm{G}+\mathrm{D}$ band & 2927.29 & 2922.45 & DRd2 \\
\hline $2 \mathrm{G}$ band & 3200.71 & 3164.627 & DR2 \\
\hline
\end{tabular}

(1) The notation for resonances is as follows. DRd1: double Raman resonance activated by disorder, 1 phonon; SR: single resonance, 1 phonon Raman allowed, DR2: double resonance, 2 phonon Raman allowed, DRd2: double Raman resonance activated by disorder, 2 phonons.

D band. The D band is the dominant Raman signature of defects/disorder. It appears in the range of 1250 $1400 \mathrm{~cm}^{-1}$ according to the literature and is related to breathing of carbon hexagons. The D band frequency $\omega$ D appears at 1357.01 and $1349.94 \mathrm{~cm}^{-1}$ for GO and r-GO, respectively (Fig. 2a and Fig. 2b). The D band in $r$-GO is also red shifted because of the development of strain in the r-GO sample. Strain greatly affects the frequency shift of the $\mathrm{D}, \mathrm{G}$ and $2 \mathrm{D}$ bands. The intensity of the D band is used to quantify defects/disorder. Since it is difficult to measure absolute intensity in Raman spectroscopy, the normalized intensity $I_{\mathrm{D}} / I_{\mathrm{G}}$ is used to measure the quantity of defects/disorder. For GO and rGO, $I_{\mathrm{D}} / I_{\mathrm{G}}$ is 1.96 and 1.61 , respectively. The broad and strong $\mathrm{D}$ band (Fig. $2 \mathrm{a}, \mathrm{b}$ ) and high $I_{\mathrm{D}} / I_{\mathrm{G}}$ ratio in GO confirm lattice distortions and a large number of $s p^{3}$. like defects that are caused by the oxidation process. The $I_{\mathrm{D}} / I_{\mathrm{G}}$ ratio for GO is 1.96 , whereas for $\mathrm{r}$-GO it is 1.61 , which indicates considerable recovery of conjugated graphitic planes upon defunctionalization of epoxy, hydroxy, carboxy and other oxygen-containing functional groups during high-pressure growth. GO has more defects and is therefore more disordered. A slight decrease in the $I_{\mathrm{D}} / I_{\mathrm{G}}$ ratio of $\mathrm{r}-\mathrm{GO}$ could be attributed to the persistence of structural defects despite the removal of oxygen-containing functional groups. These results confirm the view that, irrespective of the reduction method used, it is not possible to entirely rearrange the carbon lattice. Still, high-pressure growth approach appears to be an effective way of doing this. But in both samples, the $I_{\mathrm{D}} / I_{\mathrm{G}}$ ratio is high, which indicates the small size of GO and r-GO, the presence of turbostratic carbon and disordered structures.

Usually, the crystallite size is calculated by X-ray diffraction. Determination of the crystallite size using Raman spectroscopy is highly probable, since the process can be limited by the spatial resolution in the micrometer range, and there is no need for any sample preparation.

In $s p^{2}$ nanocarbons (GO and r-GO), Raman spectroscopy is used to measure the sizes of graphite nanocrystallites, which are defined by the in-plane crystallite size $\left(L_{a}\right)[15,16]$. As the D band arises because of the double resonance process [17] and its linewidth also correlates with the crystallite size [18], its use is highly exciting, but requires precise understanding.

$L_{a}$ is the crystallite size of GO and r-GO and can be calculated as the ratio of the $\mathrm{D}$ band intensity $\left(I_{\mathrm{D}}\right)$ to the $\mathrm{G}$ band intensity $\left(I_{\mathrm{G}}\right)$ in accordance with the following equation [19]:

$$
L_{a}(\mathrm{~nm})=2.4 \cdot 10^{-10} \lambda^{4}\left(I_{\mathrm{D}} / I_{\mathrm{G}}\right)^{-1},
$$

where $\lambda$ is the excitation laser wavelength $(532 \mathrm{~nm})$ used in Raman measurements.

For GO and r-GO, $L_{a}$ is 9.80 and $11.04 \mathrm{~nm}$, respectively. The crystallite size of $\mathrm{r}-\mathrm{GO}$ is larger than that of GO because it is calculated using the inverse ratio of the $\mathrm{D}$ band intensity $\left(I_{\mathrm{D}}\right)$ to the $\mathrm{G}$ band intensity $\left(I_{\mathrm{G}}\right)$, and for GO and $\mathrm{r}-\mathrm{GO}, I_{\mathrm{D}} / I_{\mathrm{G}}$ is 1.96 and 1.61 , respectively. Under Raman spectroscopy analysis, the crystallite size distribution is typically found between 8-12 $\mathrm{nm}$. This provides the attributes of nanotechnology based on Raman spectroscopy [20] for the development of new routes to generate nanocarbon structures.

\section{CONCLUSIONS}

In conclusion, Raman spectroscopy is already wellknown as a very powerful tool to characterize $s p^{2}$ nanocarbon (GO and r-GO) structures, for the development of nanoscience and nanotechnology. Here, we discuss in detail the Raman spectra of GO and r-GO composed of many bands/peaks, including the first-order $G$ mode and the first-order and second-order modes activated by double resonance (DR). In r-GO, the linewidth is broadened, and a slight red shift is observed in all the bands because of strain development during the hydrothermal process. The normalized intensity ratio $\left(I_{\mathrm{D}} / I_{\mathrm{G}}\right)$ for GO and r-GO is 1.96 and 1.61, respectively. In both samples, the $I_{\mathrm{D}} / I_{\mathrm{G}}$ ratio is high, which indicates their small size, the presence of turbostratic carbon and disordered structures.

The 2D band exhibits four Lorentzian peaks, and the intensity of the $2 \mathrm{D}$ band with respect to the $\mathrm{G}$ band is strongly reduced, confirming that we have successfully synthesized bilayer/trilayer GO and r-GO. For GO and $\mathrm{r}-\mathrm{GO}, L_{a}$ is 9.80 and $11.04 \mathrm{~nm}$, respectively. The existence of the $2 \mathrm{D}$ band confirms that we have successfully synthesized high-quality GO and r-GO.

This knowledge can be used as a guide for using 
Raman spectroscopy to characterize graphene derivatives, and recent applications are continuously pushing the limits of technology, for example, in graphene superlattices, but also connecting Raman spectroscopy to other fields where graphene derivatives are used, such as wastewater treatment, air purification, biotechnology, solar cells, energy storage devices and graphene-

\section{REFERENCES}

1. V. Raman, The Molecular Scattering of Light, Nobel Lecture (1930).

2. T. Ohta, A. Bostwick, J.L. McChesney, T. Seyller, K. Horn, E. Rotenberg, Phys. Rev. Lett. 98, 206802 (2007).

3. G. Eda, G. Fanchini, M. Chhowalla, Nat. Nanotechnol. 3, 270 (2008).

4. Y. Zhang, L. Guo, H. Xia, Q. Chen, J. Feng, H. Sun, Adv. Opt. Mater. 2, 10 (2014).

5. S. Stankovich, D.A. Dikin, R.D. Piner, K.A. Kohlhaas, A. Kleinhammes, Y. Jia, Y. Wu, S.T. Nguyen, R.S. Ruoff, Carbon 45, 1558 (2007).

6. Y. Zhu, S. Murali, M.D. Stoller, A. Velamakanni, R.D. Piner, R.S. Ruoff, Carbon 48, 2118 (2010).

7. S. Eigler, S. Grimm, M. Enzelbergerheim, P. Muller, A. Hirsch, Chem. Commun. 49, 7391 (2013).

8. R. Trusovas, K. Ratautas, G. Rac iukaitis, J. Barkauskas, I. Stankevic ‘iene', G. Niaura, R. Mažeikiene', Carbon 52, 574 (2013).

9. D. Yang, A. Velamakanni, G. Bozoklu, S. Park, M. Stoller, R.D. Piner, S. Stankovich, I. Jung, D.A. Field, C.A. Ventrice, et al., Carbon 47, 145 (2009). based van der Waals heterostructures.

\section{ACKNOWLEDGEMENTS}

This research is financially supported by the Science and Engineering Research Board under grant EEQ/2017/000688.

\title{
Метод вирощування при високому тиску для одержання відновленого оксиду графену і його дослідження за допомогою Раманівської спектроскопії
}

\author{
Mamta Thakran ${ }^{1}$, Sumeet Kumar ${ }^{1}$, Rohit Phogat 1 , S.K. Ray ${ }^{2}$, R. Brajpuriya ${ }^{3}$, Abhimanyu Singh Rana ${ }^{4}$ \\ Brijesh Kumar $1,5,6$
}

${ }^{1}$ Centre for Nano Science \& Technology, Amity Institute of Nanotechnology, Amity University, Haryana, India

2 Centre for Stem Cell, Amity Institute of Biotechnology, Amity University, Haryana, India

${ }^{3}$ University of Petroleum and Energy Studies, Department of Physics, School of Engineering, Dehradun, India

${ }^{4}$ BML Munjal University, Gurugram, Haryana, India

${ }^{5}$ Amity School of Engineering \& Technology, Amity University, Haryana, India

${ }^{6}$ Amity Institute of Laser Technology \& Optoelectronics, Amity University, Haryana, India

\begin{abstract}
Похідні графену демонструють надзвичайні механічні, оптичні та електронні властивості, які викликали високий науковий інтерес, і мають величезний потенціал для використання у різних додатках. Раманівська спектроскопія є універсальним інструментом для характеристики та ідентифікаціі хімічних та фрізичних властивостей похідних графену. Ми описуємо основні процеси раманівського розсіювання режимів першого (G) та другого порядку (D, G*, 2D, G + D, 2G), які мають місце в оксиді графену (GO) та відновленому оксиді графену (r-GO), підготовлених методом вирощування при високому тиску. Для r-GO лінії розширені і трохи зміщені в червону область для всіх смуг порівняно з GO через розвинення деформації під час вирощування при високому тиску (гідротермальний процес) в результаті видалення фрункціональних груп кисню. Обговорюеться нормалізоване відношення інтенсивностей $\left(I_{\mathrm{D}} / I_{\mathrm{G}}\right)$ для GO та r-GO. В обох зразках відношення $I_{\mathrm{D}} / I_{\mathrm{G}} є$ високим, що свідчить про малі розміри GO та r-GO та наявність турбостратичного вуглецю та невпорядкованих структур. Зіставлення піків 2D-смуги демонструе чотири Лоренцівські піки, а інтенсивність 2D-смуги у порівнянні із Gсмугою сильно зменшуеться, що підтверджуе, що ми успішно синтезували двошаровий/тришаровий GO та r-GO. Для GO та r-GO розраховано розмір кристалітів $\left(L_{a}\right)$. Існування $2 \mathrm{D}$-смуги підтверджує, що ми успішно синтезували високоякісні GO та r-GO.
\end{abstract}

Ключові слова: Вирощування при високому тиску, Модифікований метод Хаммера, Раманівська спектроскопія, Оксид графену, Відновлений оксид графену. 